\title{
City Performance: Chinese New Year in West Kalimantan
}

\author{
Frans Ari Prasetyo, Bandung Institute of Technology
}

The tight state control over Indonesia's ethnic Chinese communities under President Suharto's New Order (1966-1998) resulted in the political, social and cultural exclusion of those communities for many decades. In practice the New Order era saw the Indonesian government discriminate overtly against many of the country's nonindigenous populations, but it targeted the Chinese in particular. Certain businesses were closed to Chinese Indonesians, there was a quota for Chinese Indonesians in entering state universities, and there were restrictions on Chinese Indonesians joining the civil service. With the collapse of the New Order in 1998 and the subsequent lessening of state control over all Indonesian social and ethnic groups, attempts have been made to re-establish long-suppressed Chinese cultural formations and practices in Indonesia.

A case in point is the celebration of Chinese New Year, which had been banned since the passing of Order No 14/1967 by President Suharto, the ban also coinciding with the breaking off of diplomatic relations with China. Following the rapprochement between Indonesia and China at the end of the twentieth century and the beginning of the twentyfirst, the Indonesian Government has taken extraordinary steps to bring about better conditions for the country's ethnic Chinese populations. 
Given this context, it is important to establish a historical sense of the changing receptions and status of ethnic Chinese in Indonesia since the collapse of the Suharto regime in 1998. The subsequent reformation of the Indonesian political system after the Suharto era saw an immediate lessening of state control over ethnic Chinese communities, and other groups. The first post-Suharto era President, Bacharuddin Jusuf Habibie (1998-1999), issued a presidential decision that the division between pribumi (so-called Indigenous Indonesians) and non-pribumi (non-Indigenous Indonesians, including the country's communities of Chinese descent) be abolished. Attempts have been made since then to re-establish or resuscitate long-suppressed ethnic and cultural Chinese practices in Indonesia. Consequently, alternative discourses on identity have emerged, ranging from political and religious identifications to those of a more sociocultural nature.

The status of Chinese Indonesians began to change dramatically when the discriminatory distinction between pribumi and non-pribumi Indonesians was nullified formally by President Abdurrahman Wahid (popularly known as 'Gus Dur,' 19992001 ) in 2000 via government decree number $6 / 2000$. This process was further solidified with the issuing of the anti-racial discrimination law number 12/2006 on citizenship. In 2002, President Megawati Sukarnoputri (2001-2004) designated Chinese New Year-Cap Go Meh or Imlek in local idiom - as a national public holiday. Her declaration of Imlek as a public holiday followed her predecessor Gus Dur's decision to make Chinese New Year an 'optional holiday' in 2001.

Since the end of the prohibition of Chinese New Year celebrations, the night sky of towns and cities across Indonesia has been illuminated with fireworks on the eve of Chinese New Year. Most notably, the traditional street parades and accompanying festival on the fifteenth day of the New Year have been growing in size in a number of West Kalimantan towns, in particular in Singkawang, a city on the northwestern coast of the province of West Kalimantan (Borneo), with a population just under 200,000, the majority of Chinese descent. Singkawang is the only Indonesian city to have a Chinese majority. The Chinese communities in Singkawang, as with Chinese communities the world over, celebrate the advent of the lunar new year during which family reunions, and visits among family and friends, renew communal bonds. The night was traditionally marked by the firing of crackers and ritual processions intended to scare 


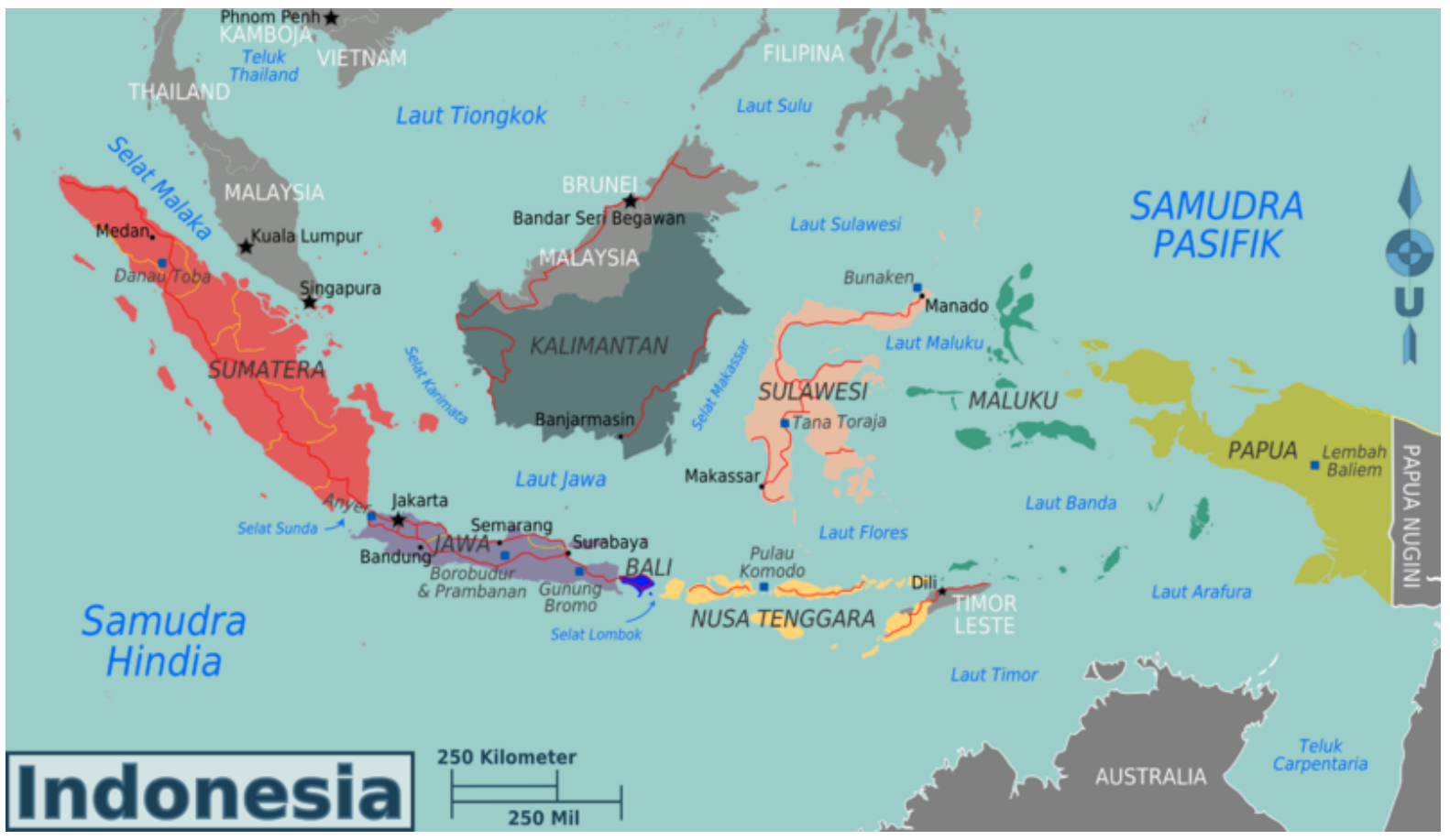

Map 1: Wiki commons, Indonesia regions map for use on Wikivoyage, Indonesian version, March 2014, Author Peter Fitzgerald, Indonesian translation by Bennylin.

\section{PETA KALIMANTAN BARAT}

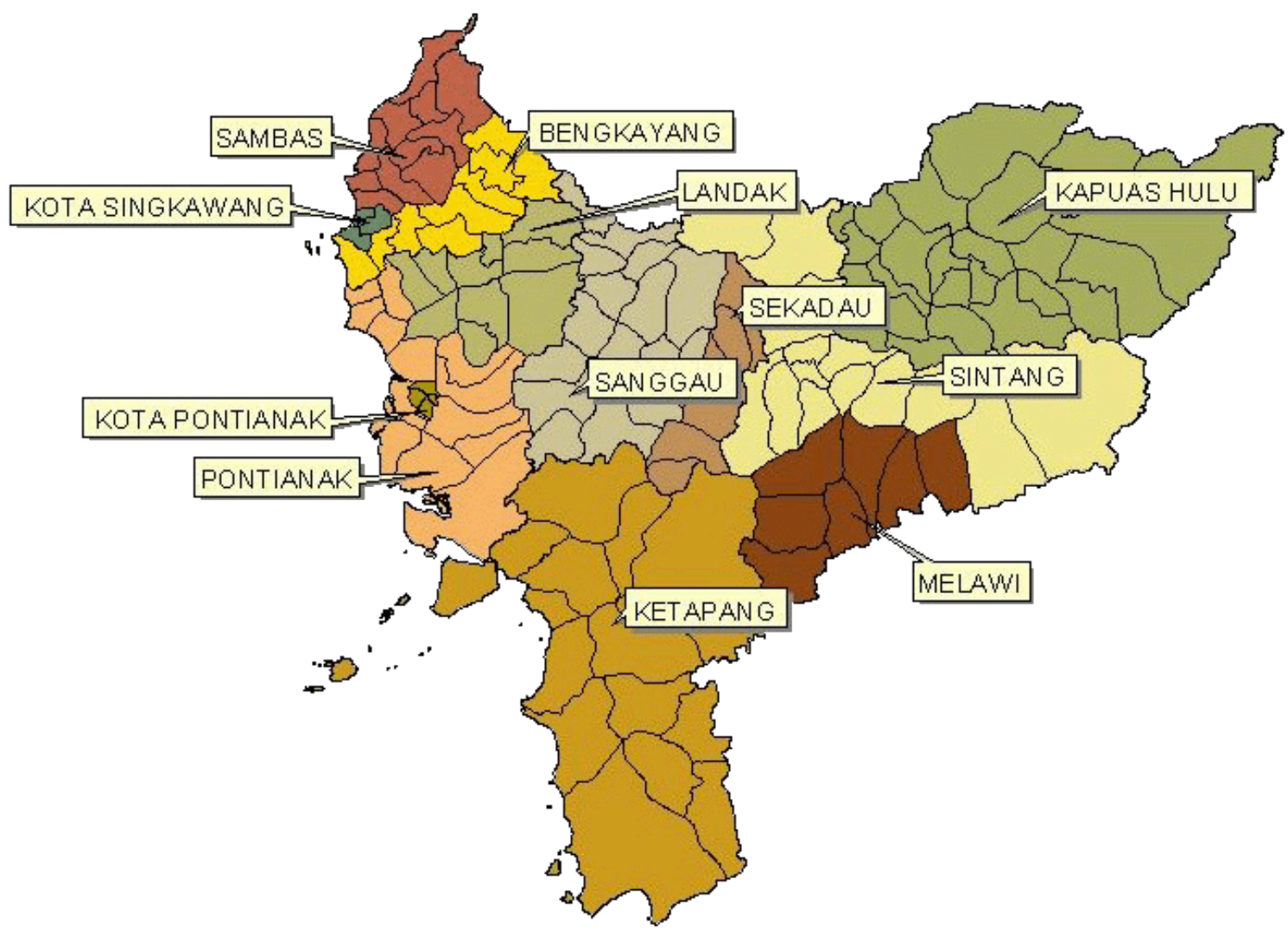

Map 2: West Kalimantan Province. Source: http://www.divrekalbar.com/2015/05/ 
the demons of bad luck away from the coming year; those rituals have been revived with a great deal of local popularity since 2002 .

That popularity reflects the long history of the New Year festival, and of local Chinese communities, in Singkawang. As noted earlier Singkawang is unique in Indonesia given it is the only city in the country with a majority Chinese Indonesian population. Hakka, a Chinese dialect, is the city's main language. The relationship between the city and the cultural history of China in Singkawang is intimate, and extends to the mutual transculturation of Chinese, Dayak (Indigenous peoples of Kalimantan) and Malay peoples in Kalimantan. This relationship, I argue, is responsible for the intensity of the local assimilation and adoption of the Chinese New Year festival. Historically, Chinese and Dayaks have been viewed in Indonesia as ethnic collaborators. Although Dayaks have clashed with Chinese in the past, such conflicts were often instigated by external parties trying to use the Dayaks to control the Chinese. Today, the street parade-cumperformance of Cap Go Meh in Singkawang provides a cultural stage on which to display Dayak and Chinese unity. Indeed, the Singkawang parade has gained such national attention that it is often featured in the official 'Visit Indonesia' tourist calendar. The Chinese New Year festival has become a key element of the city's cultural landscape and a popular tourist destination. The renewed celebration of Chinese New Year may therefore be regarded as one of the cultural milestones signalling a new era 'position' for Chinese communities in Indonesia.

These events raise important questions. What causes some Chinese New Year festivals in Indonesia to be remembered and resuscitated, while others become moments of forgotten, indeed repressed, culture? What do these processes of remembering and forgetting reveal about Chinese Indonesian desires and hopes in Indonesian national time, space and place? What are the relationships between the city and the city-street performance that epitomize the celebration of Chinese New Year? Such questions underpin my thinking about the Chinese New Year celebrations in Singkawang.

The following short narrative is intended to introduce and explain the accompanying visual narrative or visual ethnography, curated by Ilaria Vanni, of Chinese New Year performances in Singkawang, where the street parade traverses the city's main streets, 
and the parade's participants engage in a variety of rituals and performances. The visual observations that I include here help to demonstrate the role played by the streetperformance imagination in accumulating religious, cultural and social symbolism in the context of the cosmopolitan city that hosts the New Year festival. Indeed, in Singkawang, the festival seems to portray the city's ideal cosmopolitan resident as a figure who is flexible, adaptable, open to a plurality of cultures and willing to engage in, and with, multiple new cultural forms. In practice, what occurs in the festival is a reimagining of the town, a reorientation towards its complex sociocultural history and its contemporary ethnocultural realities. The parade's performance of cultural imaginations, notably Chinese cultural expressions, enacts a sense of cross-community and transhistorical connection, to the extent that participants and audience appear to embrace a national cultural imaginary that fuels the continued construction and reconstruction of Chinese Indonesian culture as at once a specific local identity place and a specific local sociocultural space.

Some of the street parade performers, acting as spirit mediums, sit on chairs embedded with knives or studded with nails, but more often they stand on the chairs with their bare feet on the sharpened edge of the knife blades. Some parade participants carry portable altars and palanquins on which are mounted images of deities. The procession includes dragon and lion dancers and a group of young men carrying staffs topped with papiermâché sculptures of the twelve Chinese zodiac animals. Carried on the shoulders of chair-bearers, the Singkawang performers ride high above the crowds, as if on parade floats. The crowd that packs the streets has a good view of these performers as they undertake acrobatic stunts, balancing on their stomachs or rocking upon the knives set into the chairs.

Among the performers, there are essentially three distinct groups - Chinese, Dayak and Malay — each distinguished by their dress. The Chinese wear the military uniforms of Ming generals and foot soldiers as depicted in Chinese opera. The Dayak costume comprises embroidered vests that resembled the traditional baju burung (bird garment) or jacket over trousers, covered by embroidered aprons that pass for the traditional sirat or cawat (loincloths). Dayak performers wear headbands or helmets decorated with hornbill and pheasant feathers. Participants who might be termed Malay also wear a distinctive costume, which comprises t-shirt (singlets) or vests over trousers with cloth 
sashes tied criss-cross over their chests and arms, and on their heads bandanas.

Such material and sartorial symbolism - which also imply that audiences will be reading proceedings and bodies for signs of participants' wealth and status - in the context of the visual performances comprising the Chinese New Year celebrations in Singkawang are alluring and powerful precisely because of the complex sociocultural and ethnic identifications that feed into such religious rituals. A focus on the performativities encapsulating Cap Go Meh in Singkawang usefully begins to recognize how the parade is not only typical of the resuscitated, historically anchored work of Chinese cultural practices and identities, but also indicative of how those practices and identities have been institutionalized into the rituals of the city, and the Indonesian nation state itself. As the following visual ethnography aims to reveal, the Cap Go Meh street parades are legible as drama, ritual theatre, a mode of visual identity-making, and political circus and thus, ultimately, as central to the iconography of the city and its ethnicized communities.

\section{Visual ethnography: Chinese New Year, Singkawang}

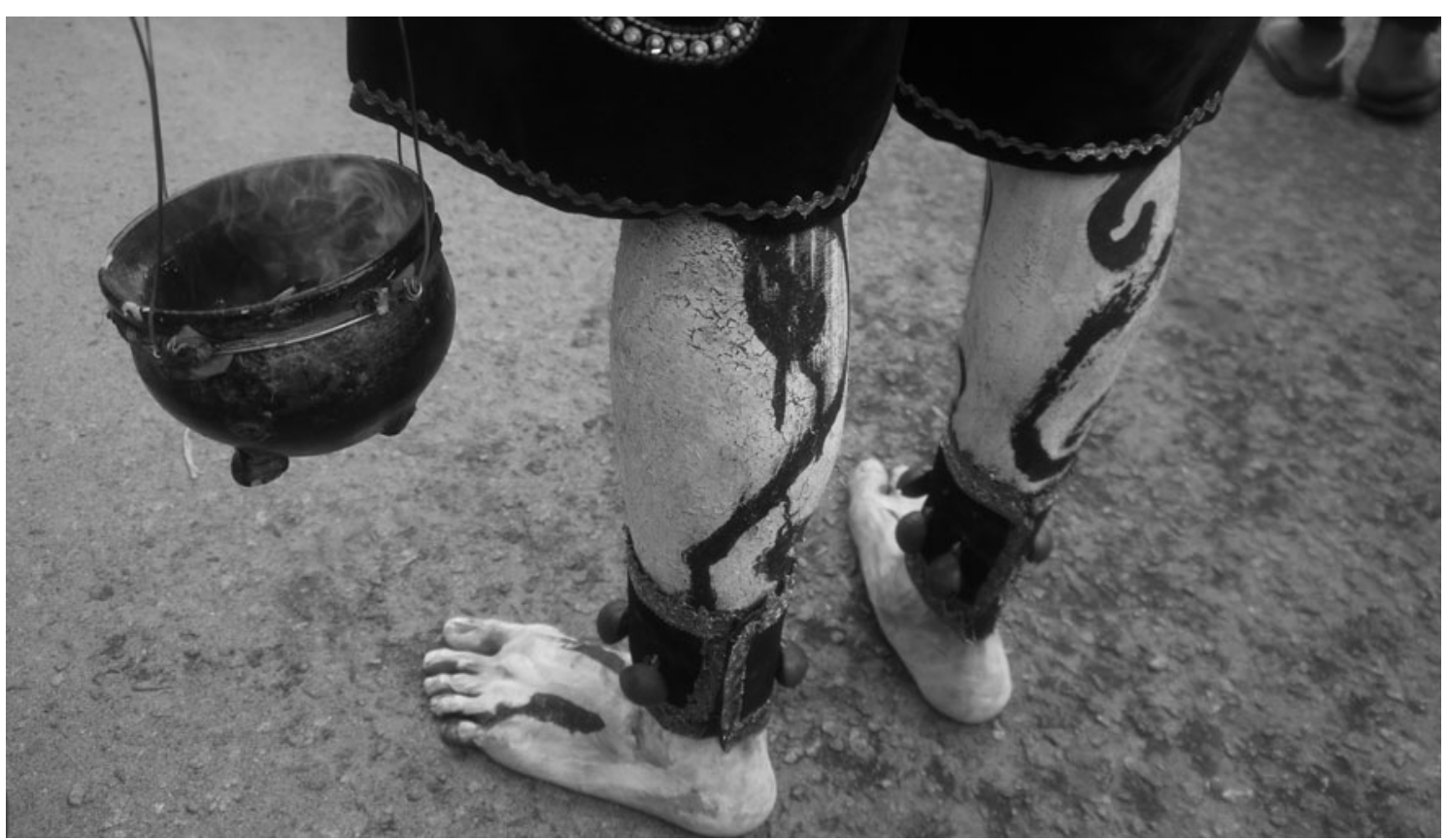

Figure 1: Chinese New year, Singkawang, digital photograph, 2015 C Frans Ari Prasetyo 


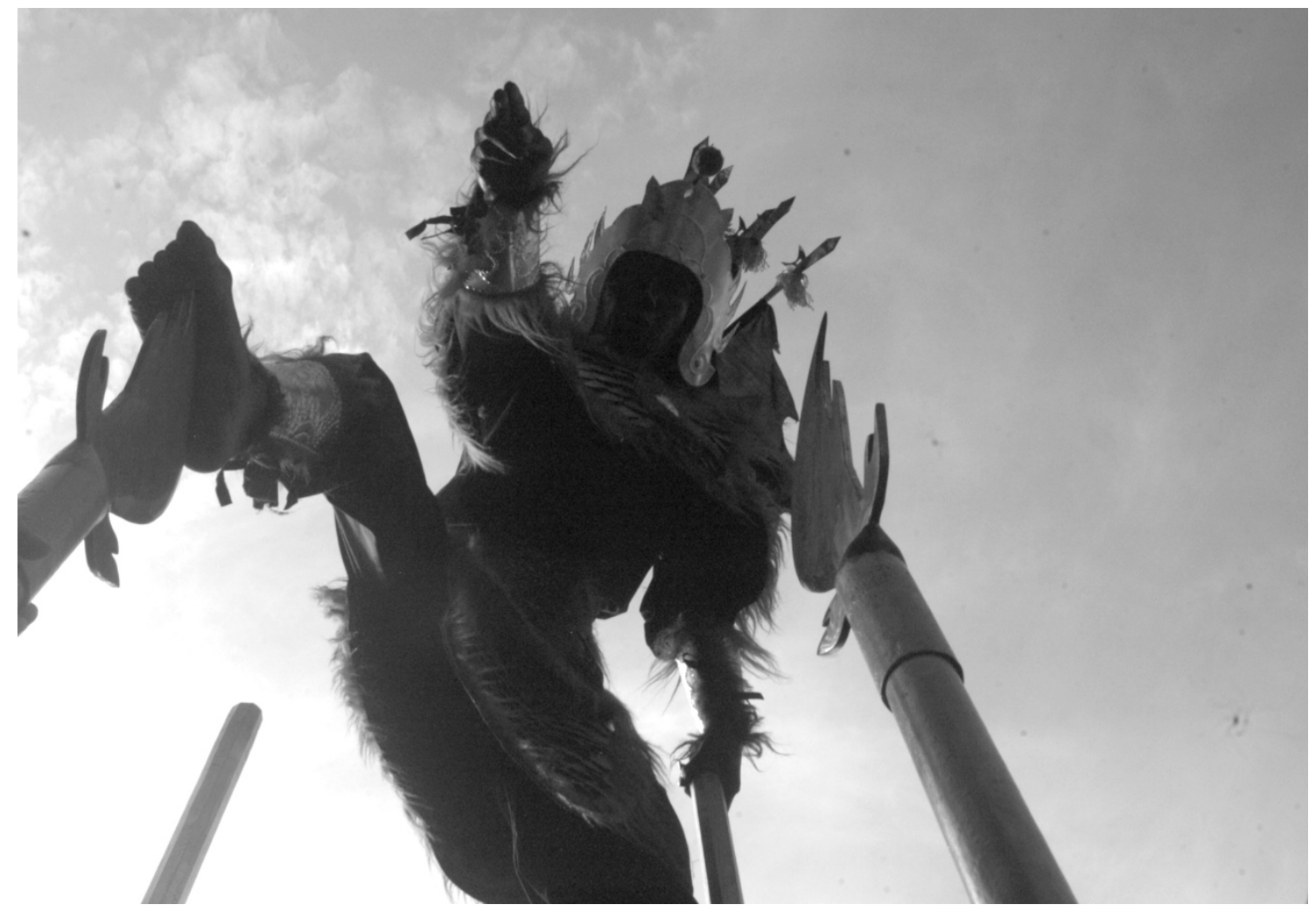

Figure 2: Chinese New year, Singkawang, digital photograph, 2015 (C) Frans Ari Prasetyo

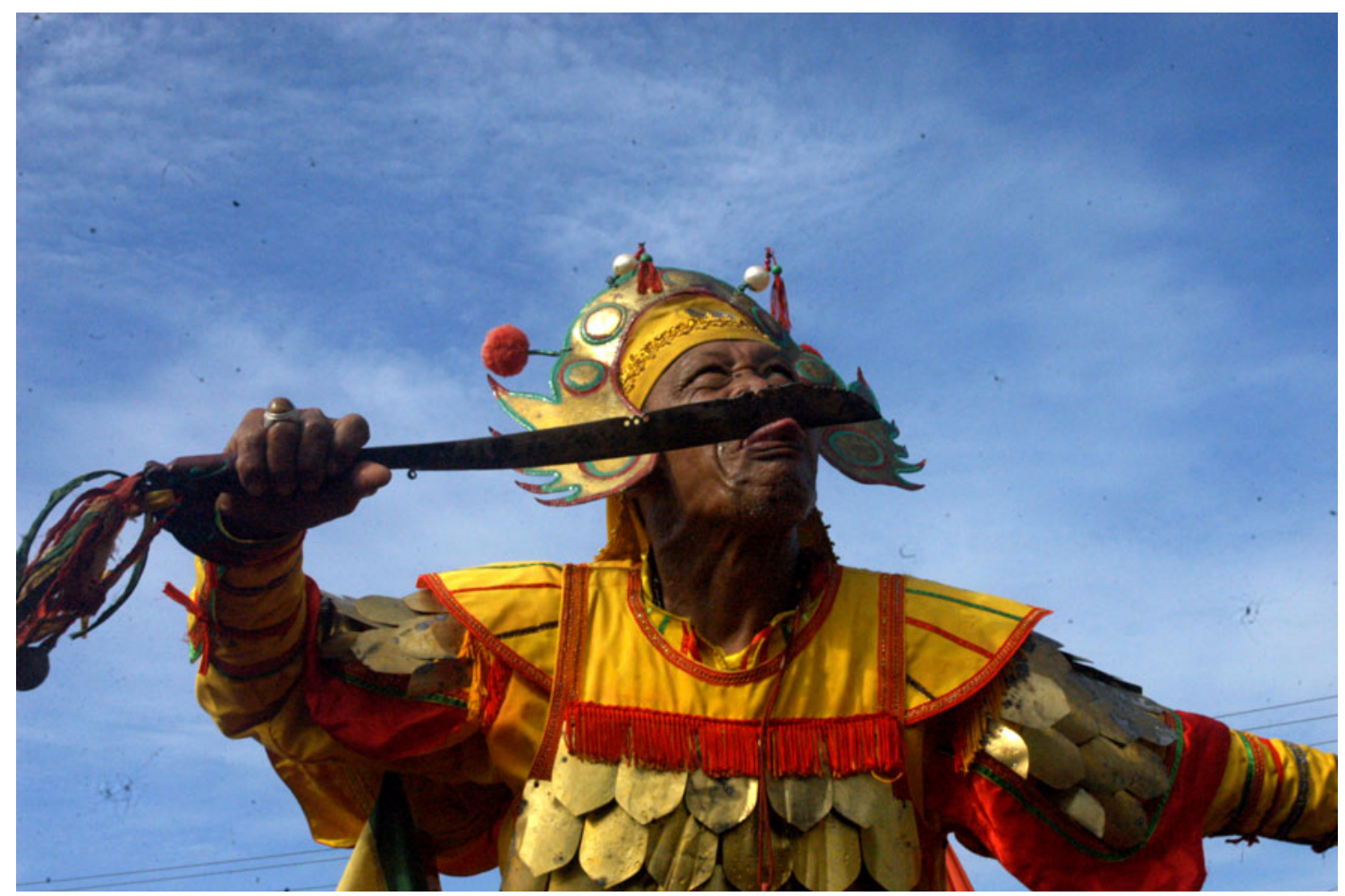

Figure 3: Chinese New year, Singkawang, digital photograph, 2015 (C) Frans Ari Prasetyo 


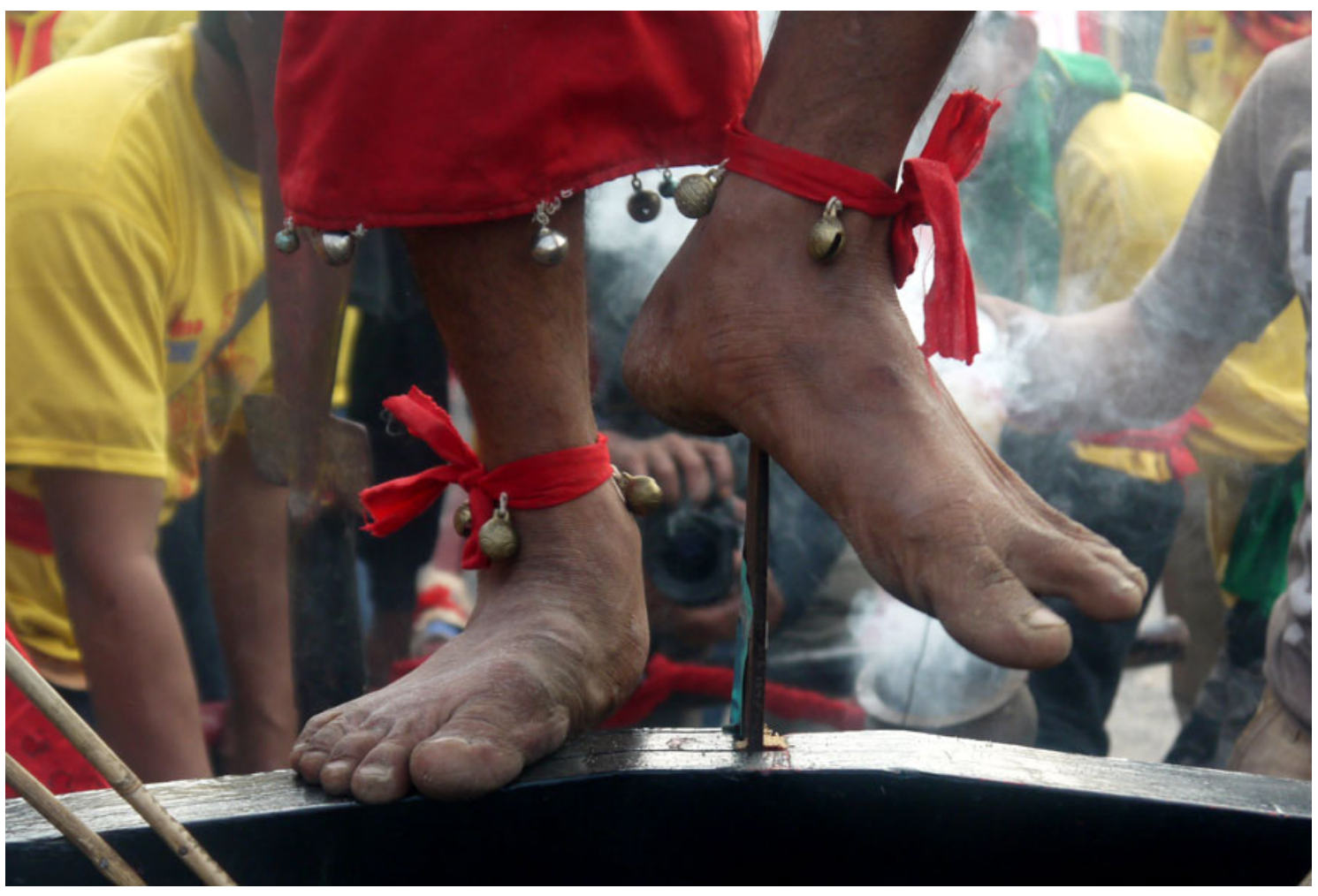

Figure 4: Chinese New year, Singkawang, digital photograph, 2015 C Frans Ari Prasetyo

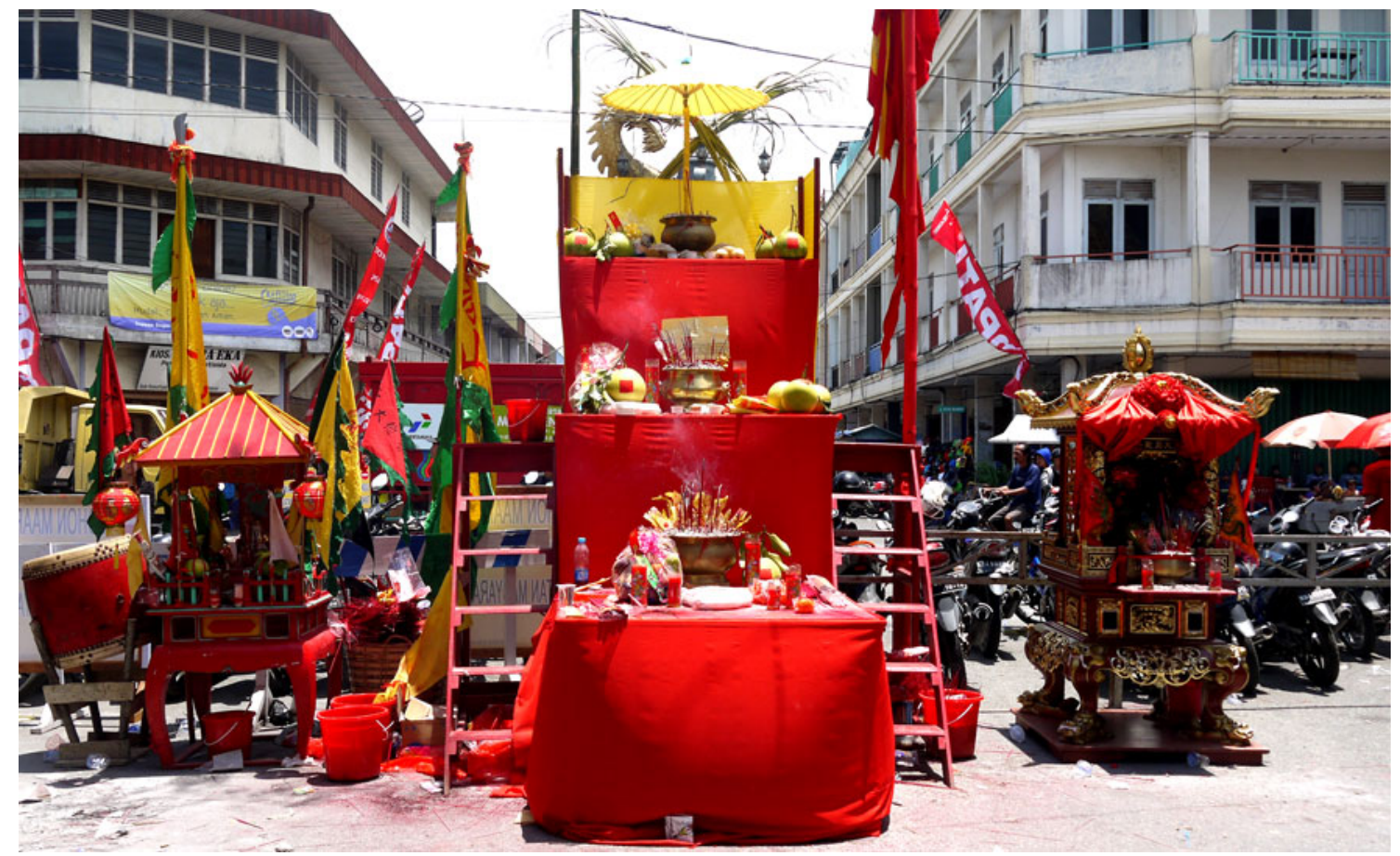

Figure 5: Chinese New year, Singkawang, digital photograph, 2015 (C) Frans Ari Prasetyo 


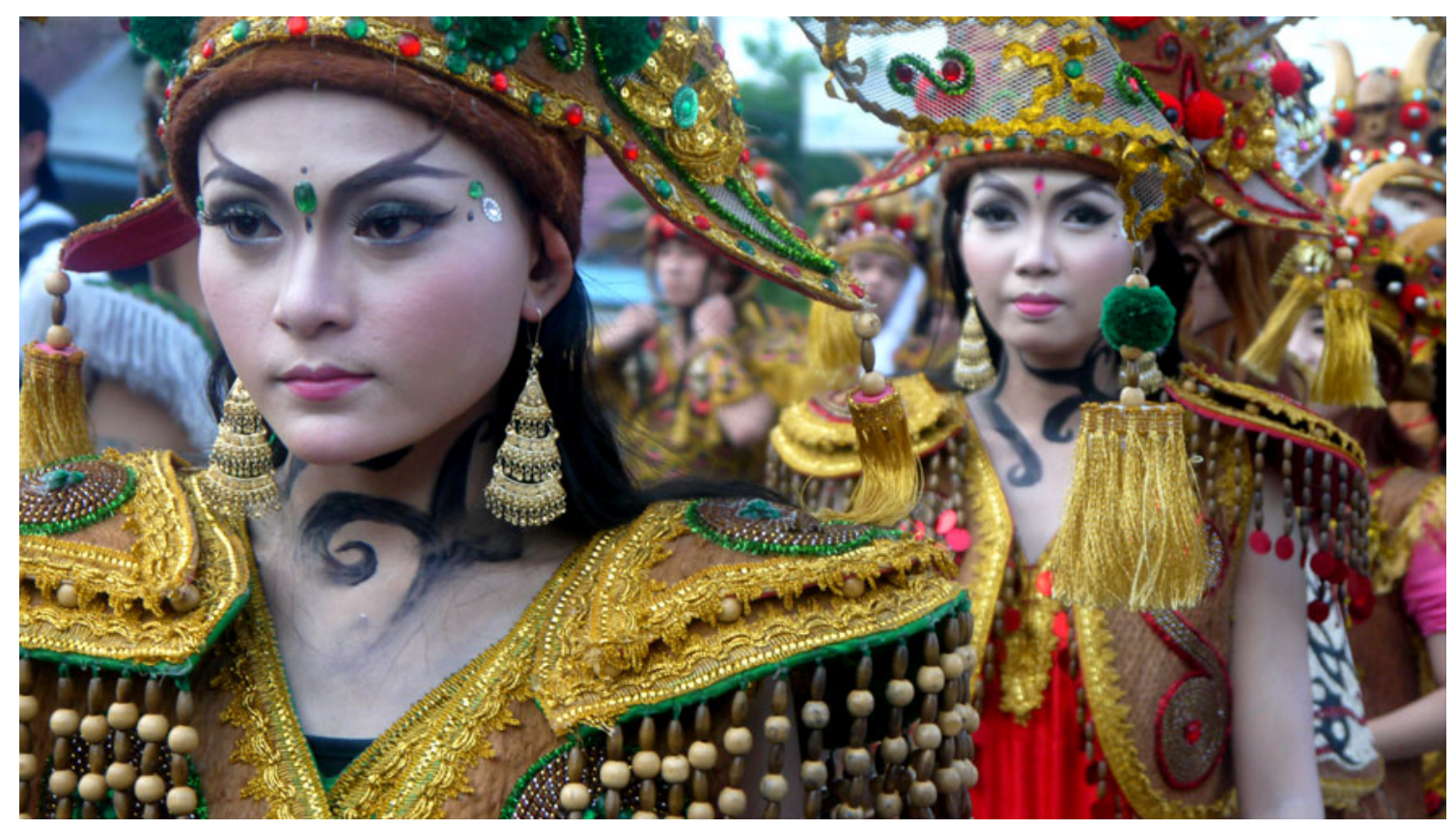

Figure 6: Chinese New year, Singkawang, digital photograph, 2015 C Frans Ari Prasetyo

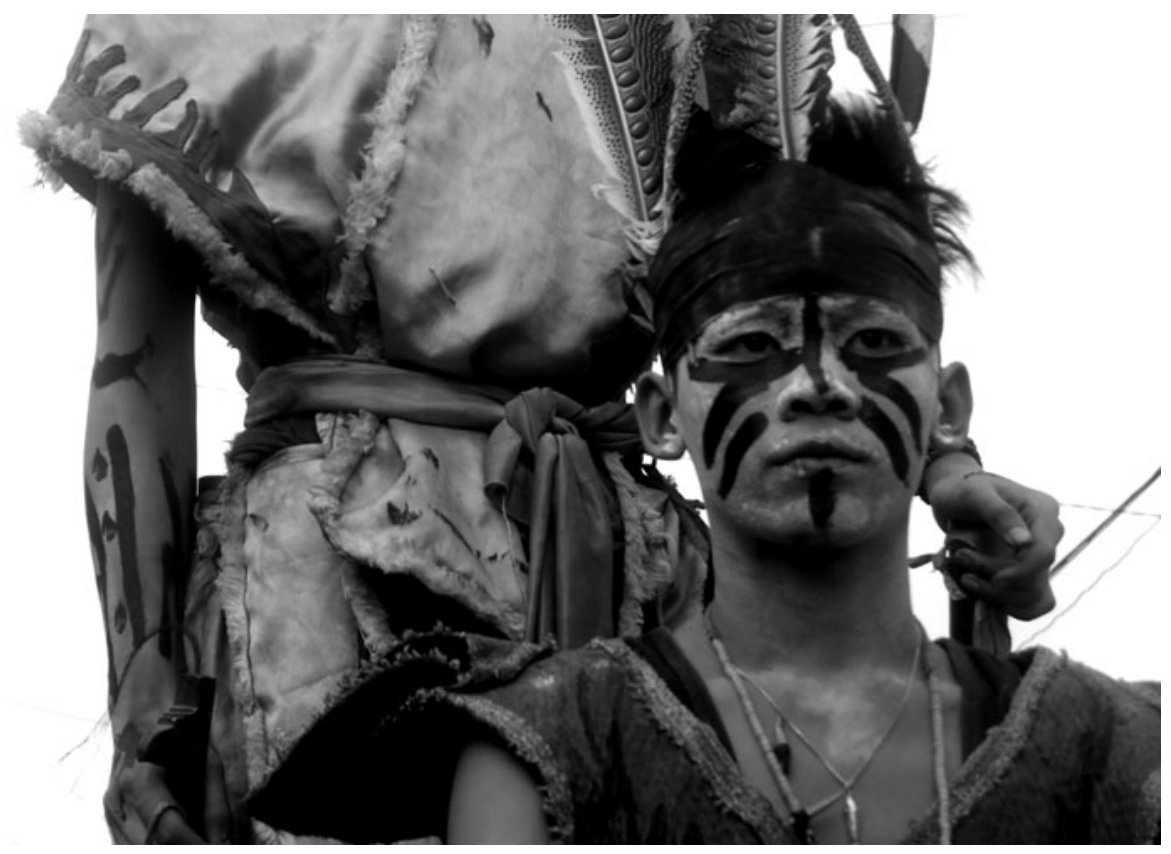

Figure 7: Chinese New year, Singkawang, digital photograph, 2015 (C) Frans Ari Prasetyo 


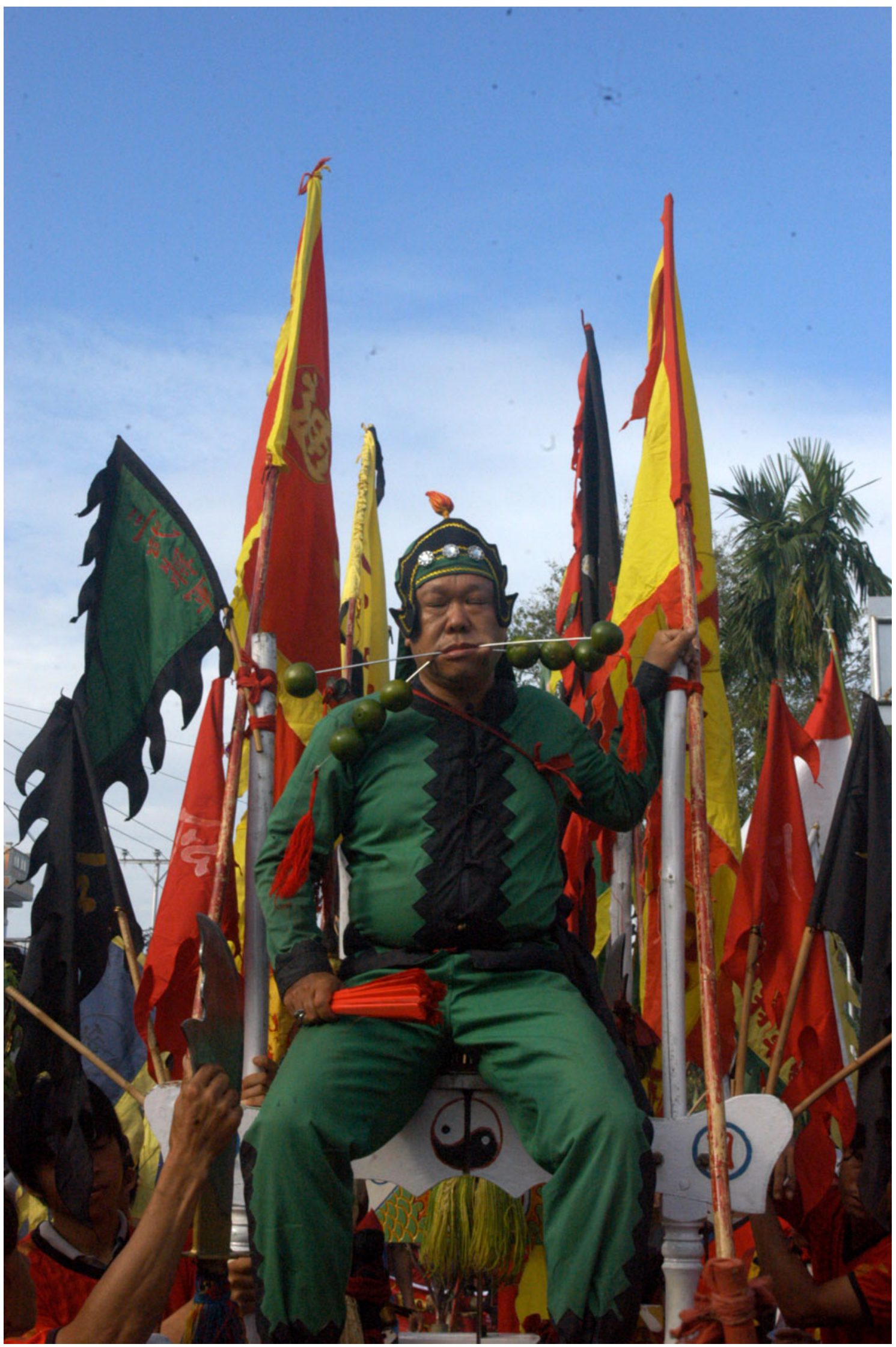

Figure 8: Chinese New year, Singkawang, digital photograph, 2015 @ Frans Ari Prasetyo 


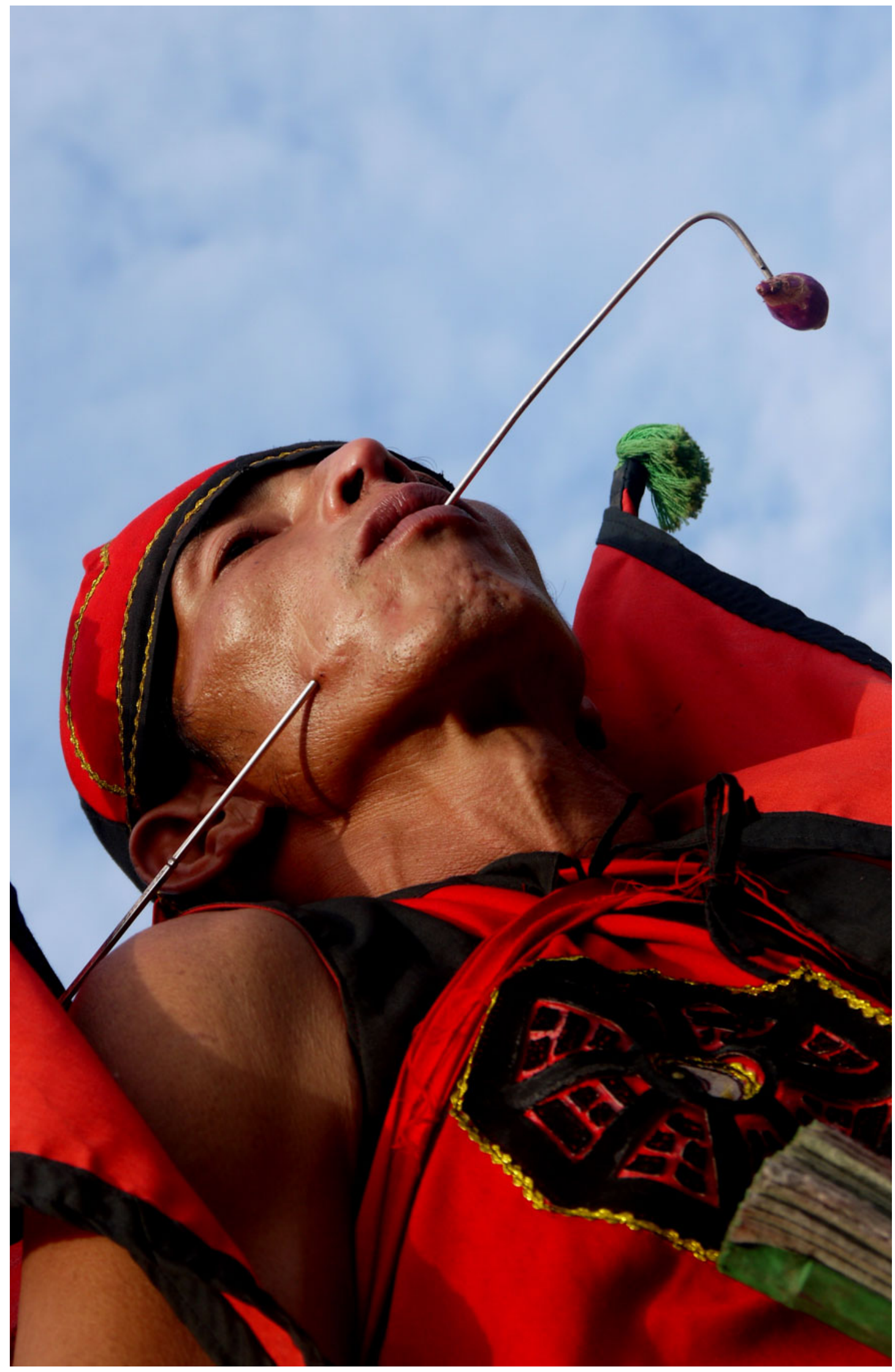

Figure 9: Chinese New year, Singkawang, digital photograph, 2015 (C) Frans Ari Prasetyo 


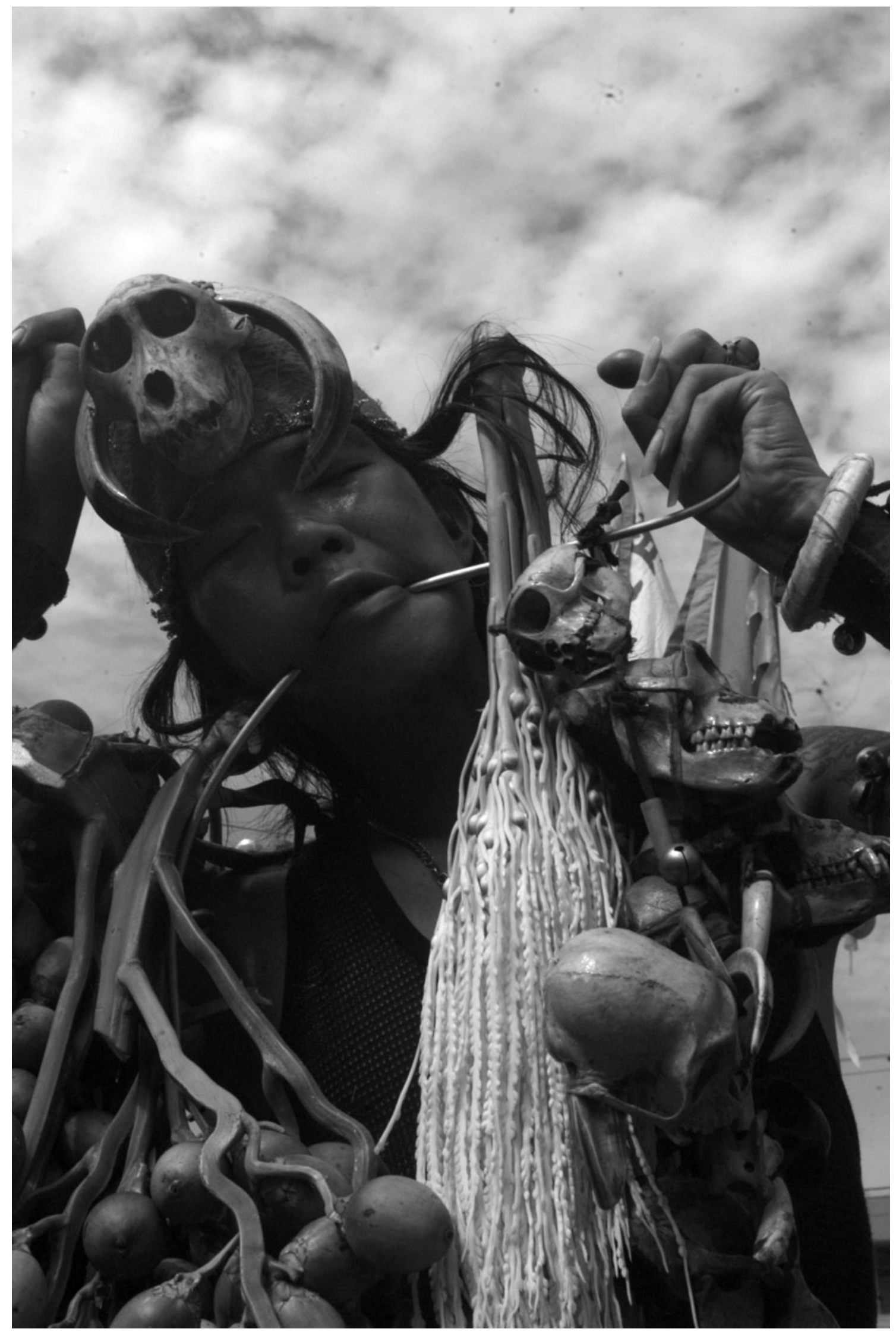

Figure 10: Chinese New year, Singkawang, digital photograph, 2015 (C) Frans Ari Prasetyo 